\title{
Position paper: Digital Engineering and Building Information Modelling in Australia
}

"First, have a definite, clear practical ideal; a goal, an objective. Second, have the necessary means to achieve your ends; wisdom, money, materials, and methods. Third, adjust all your means to that end."

\section{Aristotle}

The change in the construction industry is reflected on attempts towards integrating people, processes, and information across the life of built assets $[\underline{1}, \underline{2}]$. Developing and operating buildings and infrastructure in this scenario require that data and information about an asset's delivery and operational processes are accessible to key actors, including clients/ developers, architects, engineers, contractors, suppliers, and facility/ asset managers $[3,4]$. The construction sector increasingly relies on: (1) model's appreciation of data, information, and decision making occurring throughout the 'whole of life' of assets - the front-end of projects, procurement to schematic and detailed design, to fabrication and construction, to operations, maintenance, and decommissioning; (2) understanding both immediate and future needs of projects in terms of organisational processes, products and service offerings $[\underline{5}, \underline{6}, \underline{7}]$.

These capabilities have been initially conceived around the concept of Building Information Modelling (BIM), a 3D object-oriented approach for creating, managing and using information about various aspects of facilities, from capital phases to operations and maintenance $[\underline{8}, \underline{9}]$. Whilst many advances have been made in the application of BIM, limitations to managerial, technological and collaborative capabilities are persistent at project and operational levelsIt is in view of these limitation that the concept of Digital Engineering (DE) has emerged within the Australian construction industry. That is, DE is a more comprehensive approach to working on assets as opposed to BIM [11]; it is a holistic concept that seeks to address BIM shortcomings with an emphasis on strategic and business-oriented aspects.

Though many see the core elements of these two concepts as addressing distinct fundamental issues, some define them as similar $[\underline{12}, 13]$. Perceiving them as co-existent or even competing concepts is also common [14]. So too, there exist several criticisms relating to the limited functionality of BIM compared against $D E[\underline{15}]$. A state of confusion on conceptual definitions can impede progress towards achieving the status of an agreed norm, which is much needed by the Australian construction, where increasing levels of digital disruption and rapid technological changes are $[\underline{13}, 15]$. Besides, formal definitions of emerging digital technologies and digitally enabled methodologies are the building blocks of meaningful conversations in any field [16].

This position paper is an attempt to address the problem of DE and BIM concepts in Australia still requiring clear and agreed definitions. This paper aims at providing clear definitions of DE and BIM, their domains, how and why these two are linked, and how they relate to the broader and emerging concepts surrounding them.

\section{Australian construction industry: The need for change}

The construction industry is one of the largest sectors of the global economy [1]]. On a global scale, construction-related spending accounts for $13 \%$ and the total annual revenue of the sector is estimated to be around $\$ 10$ trillion, predicted to be up to $\$ 14$ trillion by 2025 [17 p. 1-2]. The construction industry has 
also one of the greatest economic spill over effects, namely, it represents an additional economic benefit of \$2.86 for every \$1 of construction Gross Domestic Product (GDP) [3] .

The Australian construction industry is equally important: the largest non-services sector of the economy; it employs 1.2 million Australians directly, 9.1 per cent of the total workforce, where every job in the construction industry relates to 3 jobs in the wider economy. Employment in the industry has increased by $15.6 \%$ over the last five years -2015 to $2020[18,19]$. The construction industry generates over $\$ 350$ billion in revenue, producing around $8.1 \%$ of Australia's GDP, with a projected annual growth rate of $2.5 \%$ between 2019 to 2024 [20]. As a result, even a slight improvement in the sector will carry huge positive implications for the fabric of the Australian economy $[\underline{3}, \underline{21}]$.

Despite its significance, the Australian construction industry has major challenges - high construction costs, unsatisfactory project performance, poor safety, and low construction productivity [21,22]. A prime example of these challenges surfaced in New South Wales (NSW) where around $85 \%$ of high-rise buildings built after 2000 showed some signs of structural failure [23]. Reforming the industry through adopting technological innovations can resolve many of these issues $[\underline{2}, 22,24,25]$. Of various technological innovations, BIM is recognised as the "trend of the future," a new disruptive innovation for the industry and a promising avenue towards addressing the above challenges [26 p. 483], as described next.

\section{BIM Initiatives in Australia}

BIM was first introduced as a reform initiative nearly two decades ago. In 2004, a strategy for digitalisation was introduced by releasing Construction 2020 - A Vision for Australia's Property and Construction Industry. Of the nine key visions emerging from Construction 2020, "Information and communication technologies for construction" and "virtual prototyping for design, manufacture and operation" were mentioned as the industry strategic visions for the development of the digital built environment in Australia [25]. These were subtly referring to BIM capabilities in creating virtual models for various project stages. The 2004 paper was followed up by a number of papers and policy positions: a 2009 paper $\underline{\mathrm{CRC} \text { for }}$ Construction Innovation [27] and the 2010 report of Allen Consulting Group [1]. These recommended BIM unreservedly, as a remedial solution to be widely adopted - with the potential of improving productivity in the construction sector, to raise economic wellbeing and competitiveness across the Australian economy.

Almost all major moves towards promoting a digital built environment in Australia, prior to 2018, have focused on BIM. A wide range of professional organisations and governments institutions have joined BIM advocates [28]. Professional organisation in the Australian construction industry have promoted the concept of BIM, as their primary target: NATSPEC [29], buildingSMART Australasia [30]; Australian Institute of Architects and Consult Australia [31]; Australian Institute of Building [32]; Australian Construction Industry Forum and Australasian Procurement and Construction Council [33]; AMCA [34] and recently ABAB [35] (see Hampson and Shemery [36] for details). The widespread acceptance of BIM and recognising it as the vision for the future of the Australian construction industry come from both the building industry $[\underline{1}, \underline{32}, \underline{35}]$, as well as the infrastructure sector $[\underline{37}, \underline{38}]$.

\section{Foundations of BIM}

BIM is an object-oriented approach to creating, managing and using various geometric - such as dimensions and weight - and non-geometric - such as material and cost data. BIM supports data visualisation; information management and documentation; inbuilt intelligence, analysis and simulation; and workflow management [39]. Document and information management capabilities have merged and 
evolved with BIM applications, as information embedded, appended or linked to object-based models that bring together all forms of geometric and non-geometric data $[\underline{4}, \underline{40}]$. Increasingly, BIM applications are becoming valued repositories with that integrate domain knowledge from various actors associated with projects and their supply chain [1ㅡ].

Focusing on the exchange of structured data across the entire supply chain, Volk et al. [42 p. 110] define BIM as "a tool to manage accurate building information over the whole lifecycle." Another widely-accepted source, NIBS [43 p. 3] refers to BIM as "a business process for generating and leveraging building data to design, construct and operate the asset during its lifecycle. BIM allows all stakeholders to have access to the same information at the same time through interoperability between technology platforms." The UK Building Information Modelling Task Group refers to BIM as "value creating collaboration through the entire life-cycle of an asset, underpinned by the creation, collation and exchange of shared 3D models and intelligent, structured data attached to them." [44 p. 9] Even more, the new release by Queensland Health [45] defines BIM as "sharing and leveraging of structured information over the asset lifecycle." Conceptually BIM can be used across all the phases of an asset lifecycle; however, in practice its usage beyond the design and construction phases is low [4, 46].

The ideal use of BIM across all phases of asset lifecycle is only partially realised (see Edirisinghe [47], PishdadBozorgi et al. [48], Gao and Pishdad-Bozorgi [49]); BIM is currently used only on project delivery phase to fulfil bespoke project level objectives $[\underline{6}, \underline{50}$. In fact, BIM has evolved as a set of processes and tools, not a management method [20]. Cost and time savings on projects are the selling points of BIM, where BIM is not designed to increases profitability, thrive business and improve client-customer relationship [51]; organisational and sociotechnical complexities render BIM capabilities unrecognisable beyond project settings [52]. As a workable solution, various complementary digital technologies must be leveraged alongside BIM $[\underline{52}, \underline{53}]$. BIM therefore must be integrated with other technologies, methodologies and actors [54]. The need for the reinvention of BIM [50] has given rise to the emergence of DE, as discussed below.

\section{Foundations of digital engineering (DE)}

One of the first uses of the term DE goes back to 1975, where DE was discussed in the context of electronic and logic circuit design. Back then, the term digital referred to the move from analogue to digital. Future applications were predicted to be "developing digital concepts and systems." [ 55 p. vii] and product lifecycle management (PLM) - in the manufacturing context. The aim of DE is creating a seamless line of data through interoperability across heterogeneous systems, integrated information management, facilitating information utilisation and data exchange, during the product lifecycle $[\underline{56}, \underline{57}]$. Digital engineering $(D E)$ is also closely associated with the term engineering. Engineering refers to using scientific principles to design and build various assets and artefacts, either in manufacturing, e.g. machines, vehicles, or in the built environment - bridges, tunnels, roads and buildings. Currently, all engineering disciplines have evolved to improve practices; modern engineering must be supported by large amounts of data, with the aid of computers $[\underline{58}, \underline{59}]$. This requires transforming engineering practices to digital engineering, in which technological innovations are assembled to allow for an integrated, digital component-based approach that supports lifecycle activities and develops the culture of stakeholders to work more efficiently [60]. At its core, digital engineering entails radical digital transformations, which require digital components (DC), as illustrated in Figure 1. 


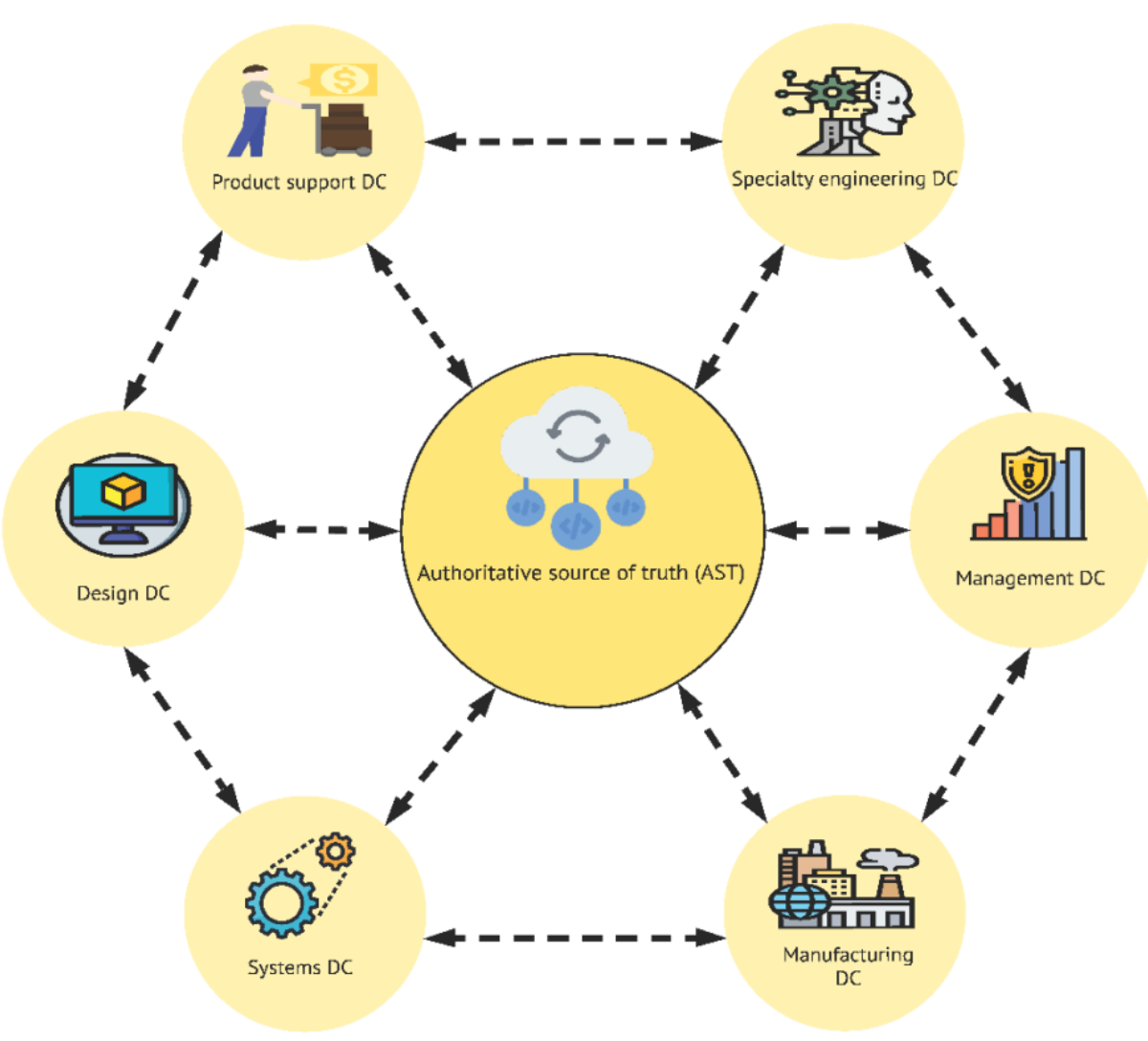

Figure 1. Core elements of DE (adapted from The Defense Department [60], Huang et al. [61])

The system and its elements, relevant processes, equipment, products, parts, functions, services, etc. in the operating environment must be presented in the form of DCs, to provide a precise and versatile representation of all these phenomena (see Figure 1). There must be a formalised DC creation strategy in place, for governing the curation, sharing, integration, and use of DC across the boundaries of disciplinary teams, organisations, and the lifecycle phases, with support of an authoritative source of truth (AST). The authoritative source of truth (AST) is needed to provide a repository and access portal of standardised DCs, data, and other digital artefacts [61].

The concept of DE is similarly relevant to the construction industry given the knowledge-intensive nature of the industry; prevalence of virtual organisations and teams; the fragmented work settings and the scattered supply chain of the sector $[2, \underline{62}]$. These inherent characteristics give rise to a wide range of issues that detrimentally affect the industry: communications being ineffective; information inconsistencies; loss of data and team members working with superseded models - irrelevant and disorganised data unfit for intended purposes $[\underline{4}, \underline{5}, \underline{10}]$. The influence of DE concepts, methods and technologies on the construction industry is stimulating changes in assumptions about data, information and knowledge management across the whole asset lifecycle. This is also transforming the way that construction companies approach business processes. Understandings of the DE concept, its technologies and requirement to support construction activities, are also making inroads into construction research domains [41] along with Australian industry and governments works [투].

\section{Digital engineering initiatives in Australia}

Recognising the serious issues, as discussed, and given the sheer size of investment in infrastructure projects in Australia, in November 2016, the Transport and Infrastructure Council endorsed the National Digital Engineering Policy Principles [64]. Transport for NSW (TfNSW) has acted as the driving force behind 
promoting the adoption of DE in Australia, to maximise quality and efficiency in delivering transport projects [65]. TfNSW has also led the National DE Working Group with senior membership from governments across Australia, as a federally sponsored group established to lead the way towards a consistent national approach to DE for transport infrastructure.

In 2014, TfNSW started a consultation schema with industry experts and major stakeholders. This was the outcome of establishing a BIM/DE working group in TfNSW, in 2012. In 2017, TfNSW released the Data and Information Asset Management Policy that formally recognises the value and critical importance of structured data. The DE Framework Program - a fully funded program - has been running since 2017, with the aim of bringing together experts from around Australia to develop practical, cost effective DE solutions based on global best practices [66]. The outcomes have resulted in the evolution and release of consecutive versions of DE Framework: Release 1 (in Sept 18), DE Framework Release 2 (Apr 19) and Release 3, in November 2019.

Currently, state governments in Australia, as well as the private sector, have recognised the great potential provided by $D E$ for improving various facets of delivering and managing buildings and infrastructure assets and networks [36,63]. Victoria is following NSW in promoting DE, by releasing Victorian Digital Asset Strategy (VDAS) [11] in 2019. And Queensland published Digital Enablement for Queensland Infrastructure, in November 2018 [67].

\section{The confusion}

According to the seminal work by Alvesson and Sandberg [68], confusion over defining concepts must be addressed where discrepancies are observed among individuals in providing definitions or when available definitions offer contradictory or competing explanations. With this in mind, there exists ongoing confusion among practitioners and researchers in defining the concepts of DE and BIM in Australia [13] . Several examples of this confusion are briefly described below.

As a common approach, typically employed by industry practitioners, is to use the terms BIM and DE interchangeably - to recognise no distinction between DE and BIM (see Northwood [12], Hardcastle and Hubert [69], Hampson and Shemery [36] and TfNSW [70]).

Some industry sources, nevertheless, stop barely short of criticising BIM as an obsolete concept; they promote DE as the current version instead $[15,71]$. Others promote the idea that DE as a process that follows BIM in the project lifecycle [14]. These positions recognise the two concepts as separate entities that cannot coexist.

Others refer to DE as a concept broader than BIM. Typically, this revolves around the notion that DE is the outcome of integrating various technologies - including BIM - to improve efficiency. This sentiment is aligned with what some researchers propose: Duc [72] offers the definition of DE as "the result of the crossover of BIM, Internet of Things (IOT) and big data." Similarly, Foster [73] purports that "Digital Engineering is a broad term which gathers several other related technologies or processes together, such as Computer-Aided Design (CAD), BIM, Geographical Information Systems (GIS) and Data Science," while BIM is the element of DE for design and construction phases. Such definitions define BIM as a subset of a wider DE ecosystem. Here, discrepancy lies in the way boundaries between DE and BIM are defined.

A more contemporary suite of logic is that DE relies on BIM as its core element [36]. It is under this notion that the list of technologies that integrate with BIM create DE. Others remain undecided, or believe that BIM can be the 'wider ecosystem', and can handle other relevant data, information, processes (see 
Golizadeh et al. [41]). Definitions in this category offer competing lists of technologies to be integrated with BIM in creating DE. Besides, the points of distinction, undermine the fundamental drivers for adopting BIM: interoperability and collaborative working; emphasise on the exchange of structured data; extension to the entire supply chain; and integration with other technologies. Though considered as a selling point for $D E$, collaboration and smooth exchange of data across a network of various data sources and interoperable systems are central elements of BIM [10]. The concept of BIM is defined based on its capability to enhance collaborative working and exchange of data across the supply chain [74]. According to Ashcraft [75] cited by Mignone et al. [10 p. 335] "attempting to implement BIM with a lack of collaboration only 'scratches the surface'."

\section{Sources of confusion}

The confusion exists, as discussed above, and two major reasons compound it. First, academic references to the concept of $\mathrm{DE}$, particularly within the construction context, are rare. To the best of the authors' knowledge, the only available definition of DE for the construction context is found in the recent paper by Golizadeh et al. [41 p. 284], in which the authors define DE as "integrating multiple digital technologiesintegrating digitisation-based on Building Information Modelling (BIM) to harness the full potentials of these applications."

Second, government publications and guidelines are not consistent. Available definitions largely emphasise "what benefits DE has in one's own context" rather than "what DE is as a concept." As a prominent example, TfNSW in the lead document on DE - Digital Engineering Standard [ㄷ] - defines it as "a collaborative way of working, using digital processes that enable more productive methods of planning, constructing, operating and maintaining TfNSW's assets." This definition mostly refers to the outcomes expected, provides an indeterminate list of technologies and offers a meaning for DE that is limited to the boundaries of transport infrastructure projects in NSW. Consequently, available definitions lack generalisability to the broader context of the Australian construction industry. Besides, government documents like the Digital Engineering Standard [76 p. 9] indicate that DE can be adopted independent of big data, BIM and loT, in contrast with industry sources that define DE as the direct outcome of integrating these technologies. So too, this view contrasts other government documents; it does not align with the definition provided in VDAS [11]], in which DE is "a convergence of emerging technologies such as BIM, GIS and other related systems for deriving better businesses, projects and asset management outcomes." The definition provided for BIM in Queensland takes a different approach, emphasising the role of BIM throughout the life cycle of assets. According to State of Queensland [67] "BIM enables a collaborative way of working using digital processes to enable more productive methods of planning, designing, constructing, operating and maintaining assets through their lifecycle."

\section{Settling the confusion}

As illustrated in Figure 2, despite some fundamental similarities, major differentiators between BIM and DE on fundamental aspects should be recognised. 


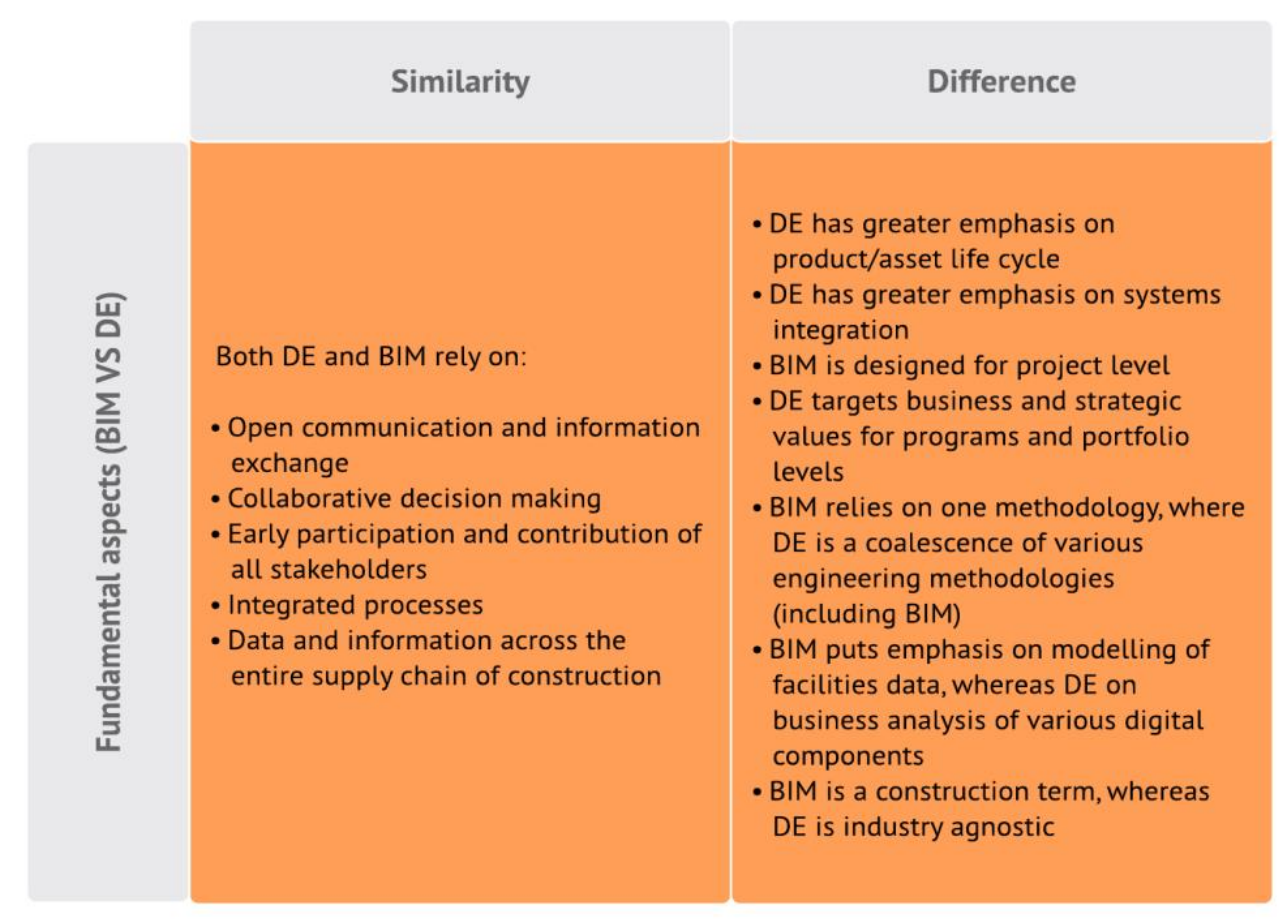

Figure 2. BIM and DE comparison

As illustrated in Figure 2, BIM is largely related to modelling of information, whereas DE deals with achieving desired levels of systems integration and strategic business perspective of the latter. DE relies on a versatile set of methodologies to inform strategic decision-making, not only in projects - that BIM does but also across program and portfolio levels (see Figure 3 ).

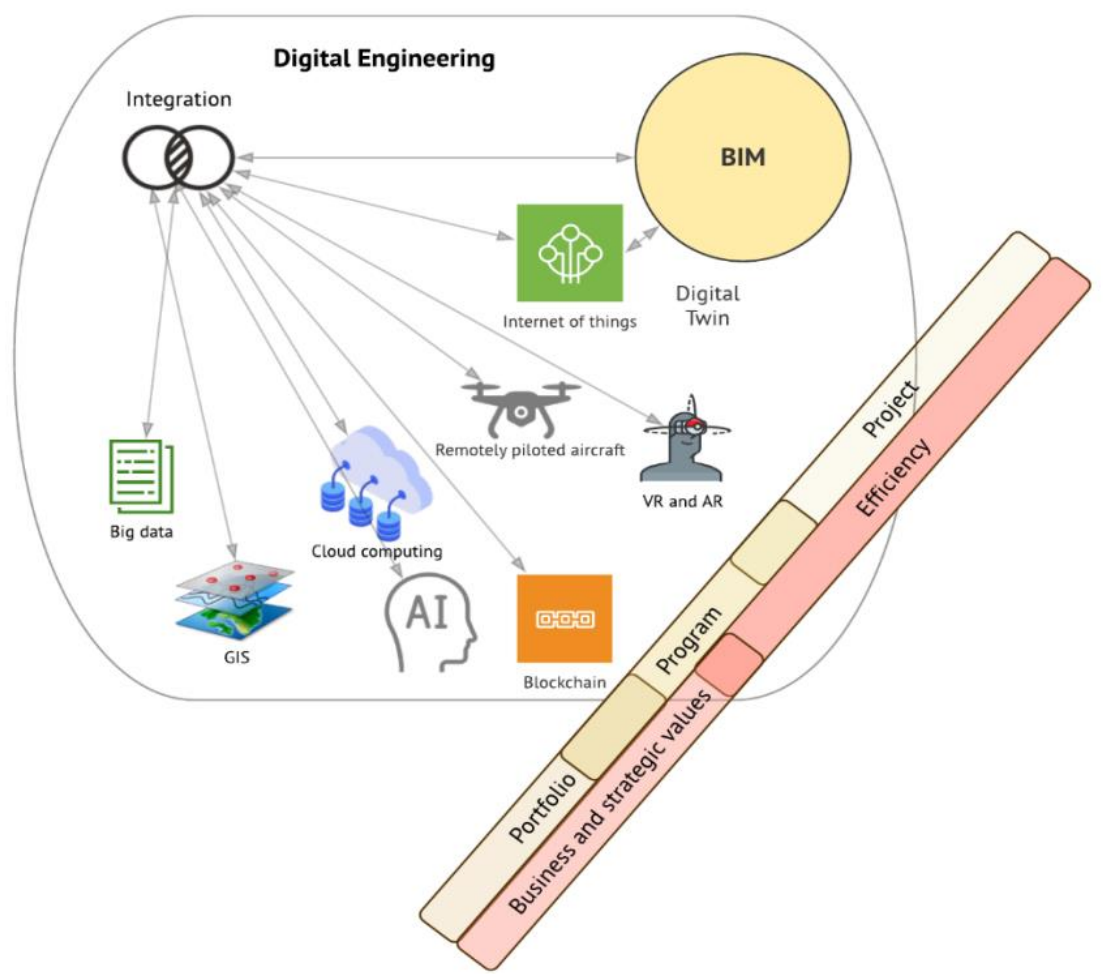

Figure 3. BIM, DE and other fundamental concepts 
Unlike BIM, DE is seen as a holistic business concept; it encompasses both a business approach and a set of engineering toolsets to apply scientific methods to large datasets for problem solving. These methodologies have roots in various disciplines and domains, where BIM is mostly confined to construction activities. Engineering 'systems' are thus the enablers of $D E$, that serve as hubs of product data [41], to support collaborative design and production processes; use; traceability and management of information across the extended enterprise; and for all actors involved in the realisation and operations of facilities.

Digital twin represents the ideal application of BIM in a project, where DE implementation in ultimate levels should result in the implementation of Industry 4.0 [61], where cyber-physical systems integrate into a new production system and economy. The list of technologies and methodologies to be integrated into BIM in creating DE is hence dictated by the enabling systems of Industry 4.0 [61]. There is a broad literature about technologies that form Industry 4.0. Various sources introduce different list of technologies, many of which are related to production, operation and services of the manufacturing industry [77]. Figure 3 provides a reference for the technologies proposed in this paper as a contextualised version for construction settings.

In the construction context, implementing DE means that information related to physical aspects of construction projects and the virtual computational space are highly synchronised. This allows for a whole new degree of control, surveillance, transparency and efficiency in the construction process. In DE, two parallel networks are linked: a physical network of interconnected tools related to various technologies (see Figure 3) and a cyber network of intelligent controllers and the communication links among them.

\section{Concluding remarks}

This position paper has sought out to settle the confusion between the concepts of BIM and DE. Both of these concepts have been used interchangeably in industry and academic communities. As discussed, the sources of this confusion are found in the academic discourse, as well as, in professional and government documents. These have obscured the boundaries of these two concepts. By reviewing the origins and foundations of BIM and DE, this paper contributes to increasing the collective understanding across industry and academia of how these concepts came into being and what are their implications for practice. Although, this positions paper focused primarily in Australia, there exist similar patterns to other national systems.

After looking at the origins of each, to be found at product modelling and data science for BIM and DE respectively, their main similarities were found in their focus on communication, information exchange and collaboration. This implies that the importance of both BIM and DE for digital practices, which are innately collaborative, is paramount. Nevertheless, significant differences have been discovered especially with regards to life cycle consideration and systems integration that are more emphasised in DE over BIM. BIM has been usually associated with the front-end and the execution of projects, whereas DE application areas span across the whole project lifecycle, including operation and maintenance. At the same time, BIM is designed primarily for modelling and representation of information in projects as opposed to DE focusing on data analyses for informed decision-making at a strategic level.

From a broader perspective, BIM is an element among other methodologies that collectively make up DE and feed DE for data analysis purposes through their links with the physical domain. Therefore, BIM can be described as a subset of DE. At the same time, DE is an industry agnostic term that can help initiate discussions and facilitate knowledge transfer to construction from other industries, such as manufacturing 
and computer science, where digital technologies have been highly developed, tested and diffused across these sectors. Moving from a BIM-centric terminology towards DE is a step forward for further digitalising the construction sector and allowing knowledge externalities to contribute to shaping its future, as one step towards the adoption of Industry 4.0 in the construction domain.

\section{References}

[1] Allen Consulting Group. 2010. Productivity in The Buildings Network: Assessing the Impacts of Building Information Models [Online]. Available: https://buildingsmart.org.au/wpcontent/uploads/2014/03/BIM Economic Study Final-Report 290ct2010.pdf [Accessed 5 November 2019].

[2] M.R. Hosseini, N. Chileshe, J. Zuo, B. Baroudi, Approaches for implementing ICT technologies within construction industry, Australasian Journal of Construction Economics and Building: The Conference Series 1 (2) pp. 1-12, (2012),

[3] L.G. Sategna, D. Meinero, M. Volontà, Digitalising the Construction Sector, Committee for European Construction Equipment, Brussels, Belgium, 2019

[4] M.R. Hosseini, Integrating BIM into facility management, International Journal of Building Pathology and Adaptation 36 (1) pp. 2-14, (2018), 10.1108/IJBPA-08-2017-0034

[5] J.R. Jupp, V. Singh, A PLM perspective of BIM research initiatives, Int. J. Prod. Lifecycle Manage 9 pp. 180197, (2016),

[6] R. Woodhead, P. Stephenson, D. Morrey, Digital construction: From point solutions to loT ecosystem, Automation in Construction 93 pp. 35-46, (2018),

[7] B. Succar, E. Poirier, Lifecycle information transformation and exchange for delivering and managing digital and physical assets, Automation in Construction 112 pp. 103090, (2020),

[8] Ž. Turk, Ten questions concerning building information modelling, Building and Environment 107 pp. 274284, (2016), 10.1016/j.buildenv.2016.08.001

[9] F. Khosrowshahi, Y. Arayici, Roadmap for implementation of BIM in the UK construction industry, Engineering, Construction and Architectural Management 19 (6) pp. 610-635, (2012), 10.1108/09699981211277531

[10] G. Mignone, M.R. Hosseini, N. Chileshe, M. Arashpour, Enhancing collaboration in BIM-based construction networks through organisational discontinuity theory: a case study of the new Royal Adelaide Hospital, Architectural Engineering and Design Management pp. 333-352, (2016), 10.1080/17452007.2016.1169987

[11] Office of Projects Victoria. 2019. Victorian Digital Asset Strategy [Online]. Available: http://www.opv.vic.gov.au/Victorian-Chief-Engineer/Victorian-Digital-Asset-Strategy [Accessed 11 November 2019].

[12] C. Northwood. 2013. Digital engineering [Online]. RIBA Enterprises Ltd. Available: https://www.thenbs.com/knowledge/digital-engineering [Accessed 20 November 2019].

[13] J. Foster. 2019. Digital Engineering Series: Part 1 - Steve Fox, BIM Consulting [Online]. Linkedln Corporation. Available: https://www.linkedin.com/pulse/digital-engineering-series-what-does-mean-property-industryfoster/ [Accessed 20 November 2019].

[14] HKIE. 2019. From BIM to digital engineering [Online]. BCI Asia Construction Information Ltd. Available: http://www.constructionplusasia.com/hk/from-bim-to-digital-engineering/ [Accessed 20 November 2019].

[15] A. Krebs. 2018. BIM is dead. Long live digital engineering [Online]. CIBSE Journal. Available: https://www.cibsejournal.com/opinion/bim-is-dead-long-live-digital-engineering/ [Accessed 20 November 2019].

[16] J.G. Wacker, A theory of formal conceptual definitions: developing theory-building measurement instruments, Journal of Operations Management 22 (6) pp. 629-650, (2004),

http://dx.doi.org/10.1016/j.jom.2004.08.002

[17] F. Barbosa, J. Woetzel, J. Mischke, M.J. Ribeirinho, M. Sridhar, M. Parsons, N. Bertram, S. Brown. 2017. Reinventing construction through a productivity revolution [Online]. McKinsey Global Institute. Available: https://www.mckinsey.com/industries/capital-projects-and-infrastructure/our-insights/reinventingconstruction-through-a-productivity-revolution [Accessed 12 September 2019]. 
[18] LMIP. 2020. Construction [Online]. Labour Market Information Portal. Available:

https://Imip.gov.au/default.aspx?LMIP/GainInsights/IndustryInformation/Construction [Accessed 16 June 2020].

[19] M. Loosemore. 2020. We may live to regret open-slather construction stimulus [Online]. The Conversation Media Group Ltd. Available: https://theconversation.com/we-may-live-to-regret-open-slather-constructionstimulus-139967 [Accessed 16 June 2020].

[20] AISC. 2019. Industry Directory [Online]. The Australian Industry and Skills Committee (AISC) Available: https://nationalindustryinsights.aisc.net.au/industries [Accessed 30 October 2019].

[21] P. Leviäkangas, S. Mok Paik, S. Moon, Keeping up with the pace of digitization: The case of the Australian construction industry, Technology in Society 50 pp. 33-43, (2017),

https://doi.org/10.1016/j.techsoc.2017.04.003

[22] M. Loosemore. 2019. Australia's construction industry must unite around a cohesive strategy [Online]. Spinifex Available: https://www.thefifthestate.com.au/innovation/building-construction/australiasconstruction-industry-must-unite-around-a-cohesive-strategy/ [Accessed 30 October 2019].

[23] A. Ghosh, D.J. Edwards, M.R. Hosseini, R. Al-Ameri, J. Abawajy, W.D. Thwala, Real-time structural health monitoring for concrete beams: a cost-effective 'Industry 4.0'solution using piezo sensors, International Journal of Building Pathology and Adaptation pp., (2020),

[24] A. Gruszka, J.R. Jupp, G. De Valence. 2017. Digital Foundations: How Technology is Transforming Australia's Construction Sector [Online]. Australia: OPUS at UTS. Available:

https://opus.lib.uts.edu.au/handle/10453/124861 [Accessed 30 October 2019].

[25] K.D. Hampson, P. Brandon, Construction 2020-A vision for Australia's Property and Construction Industry, CRC Construction Innovation, Queensland University of Technology, 2004.0975097725

[26] Y. Tulubas Gokuc, D. Arditi, Adoption of BIM in architectural design firms, Architectural Science Review 60 (6) pp. 483-492, (2017), 10.1080/00038628.2017.1383228

[27] CRC for Construction Innovation. 2009. National Guidelines for Digital Modelling [Online]. QUT, Australia: Cooperative Research Centre for Construction Innovation. Available: http://www.constructioninnovation.info/images/pdfs/BIM Guidelines Book 191109 lores.pdf [Accessed 5 November 2019].

[28] G. Brewer, T. Gajendran, R. Le Goff. 2012. Building information modelling (BIM): Australian perspectives and adoption trends [Online]. Tasmanian Building and Construction Industry Training Board. Available:

https://www.tbcitb.com.au/storage/bimaustralia-final.pdf [Accessed 12 November 2019].

[29] NATSPEC. 2019. NATSPEC National BIM Portal [Online]. NATSPEC Construction Information Systems Limited. Available: https://bim.natspec.org/ [Accessed 12 November 2019].

[30] buildingSMART Australasia. 2012. National Building Information Modelling Initiative. Vol.1, Strategy [Online]. buildingSMART Australasia,. Available: https://buildingsmart.org.au/wpcontent/uploads/2014/03/NationalBIMIniativeReport 6June2012.pdf [Accessed 11 Novermber 2019].

[31] D. Holzer, C. Agar, N. Burt, R. Choy, R. Clark, I. Cumming, J. Hainsworth, K. Howie, J. Lemercier, T. Maple, C. McCormack, P. Megram, S. Nelson, P. Nunn, D. Sutherland. 2012. BIM in Practice - BIM ! What is it ! [Online]. Australian Institute of Architects and Consult Australia. Available: https://wp.architecture.com.au/bim/wpcontent/uploads/sites/40/2014/07/BIM-What-is-it.pdf [Accessed 13 November 2019].

[32] AIB. 2013. AIB Policy on Building Information Modelling (BIM) [Online]. Australian Institute of Building Available: https://aib.org.au/wp-content/uploads/2014/11/AIB-Policy-on-Building-Information-ModellingBIM-FINAL.pdf [Accessed 12 November 2019].

[33] ACIF, APCC. 2017. Building Information Modelling (BIM) Knowledge and Skills Framework [Online]. Australian Construction Industry Forum and Australasian Procurement and Construction Council Available: https://www.acif.com.au/documents/item/799 [Accessed 11 Novermber 2019].

[34] AMCA. 2012. BIM-MEPAUS Road Map - 2012 Parliamentary Launch [Online]. Air Conditioning and Mechanical Contractors' Association (AMCA). Available: https://www.bimmepaus.com.au/initiative/bim-mepaus-roadmap-2012-parliamentary-launch/ [Accessed 12 November 2019].

[35] ABAB. 2018. Submission to Australian Government: Department of Industry, Innovation and Science [Online]. The Australasian BIM Advisory Board (ABAB). Available: https://consult.industry.gov.au/portfolio-policy-andinnovation-strategy/the-digital-economy/consultation/download public attachment?sqld=question.201709-14.5563483188-publishablefilesubquestion\&uuld=705978137 [Accessed 11 November 2019]. 
[36] K. Hampson, A. Shemery. 2018. Digitally Engineering the Future - Opportunities for VicRoads [Online]. Sustainable Built Environment National Research Centre (SBEnrc). Available:

https://sbenrc.com.au/app/uploads/2018/09/P2.46VicRoadsCaseStudy-FINAL.pdf [Accessed 14 November 2019].

[37] The Productivity Commission. 2014. Productivity Commission Report into Public Infrastructure 2014 [Online]. The Productivity Commission. Available: https://www.pc.gov.au/inquiries/completed/infrastructure/report [Accessed 12 November 2019].

[38] Infrastructure Australia. 2016. Australian Infrastructure Plan: Priorities and reforms for our nation's future [Online]. Infrastructure Australia. Available:

https://www.infrastructureaustralia.gov.au/sites/default/files/2019-06/Australian Infrastructure Plan.pdf [Accessed 12 November 2019].

[39] J.R. Jupp, V. Singh, Similar Concepts, Distinct Solutions, Common Problems: Learning from PLM and BIM Deployment, Springer Berlin Heidelberg, Berlin, Heidelberg, 2014, pp. 31-40

[40] B. Becerik-Gerber, F. Jazizadeh, N. Li, G. Calis, Application Areas and Data Requirements for BIM-Enabled Facilities Management, Journal of Construction Engineering and Management 138 (3) pp. 431-442, (2012), doi:10.1061/(ASCE)CO.1943-7862.0000433

[41] H. Golizadeh, C.K.H. Hon, R. Drogemuller, M. Reza Hosseini, Digital engineering potential in addressing causes of construction accidents, Automation in Construction 95 pp. 284-295, (2018),

https://doi.org/10.1016/i.autcon.2018.08.013

[42] R. Volk, J. Stengel, F. Schultmann, Building Information Modeling (BIM) for existing buildings - Literature review and future needs, Automation in Construction 38 pp. 109-127, (2014),

https://doi.org/10.1016/j.autcon.2013.10.023

[43] NIBS. 2015. National BIM Standard - United States ${ }^{\circledR}$ Version 3 - Terms and Definitions [Online]. National Institute of Building Sciences. Available: https://www.nationalbimstandard.org/nbims-us [Accessed 1 November 2019].

[44] A. Sawhney, A.R. Khanzode, S. Tiwari, Building Information Modelling for Project Managers, London, UK, 2017

[45] Queensland Health. 2019. Queensland Health Project Information Requirements - Building Information Modelling [Online]. State of Queensland (Queensland Health). Available:

https://www.health.qld.gov.au/ data/assets/pdf file/0033/860694/qh-gdl-374-9.pdf [Accessed 20 November 2019].

[46] E. Pärn, D. Edwards, Conceptualising the FinDD API plug-in: A study of BIM-FM integration, Automation in Construction 80 pp. 11-21, (2017),

[47] R. Edirisinghe, Building information modelling for facility management: are we there yet?, Engineering, Construction and Architectural Management 24 (6) pp. 1119-1154, (2017), 10.1108/ECAM-06-2016-0139

[48] P. Pishdad-Bozorgi, X. Gao, C. Eastman, A.P. Self, Planning and developing facility management-enabled building information model (FM-enabled BIM), Automation in Construction 87 pp. 22-38, (2018), https://doi.org/10.1016/j.autcon.2017.12.004

[49] X. Gao, P. Pishdad-Bozorgi, BIM-enabled facilities operation and maintenance: A review, Advanced Engineering Informatics 39 pp. 227-247, (2019), https://doi.org/10.1016/j.aei.2019.01.005

[50] C. Merschbrock, M.R. Hosseini, I. Martek, M. Arashpour, G. Mignone, Collaborative Role of Sociotechnical Components in BIM-Based Construction Networks in Two Hospitals, Journal of Management in Engineering 34 (4) pp. 05018006, (2018), doi:10.1061/(ASCE)ME.1943-5479.0000605

[51] V.P. Bhatija, N. Thomas, N. Dawood, A Preliminary Approach towards Integrating Knowledge Management with Building Information Modeling (K BIM) for the Construction Industry, International Journal of Innovation, Management and Technology 8 (1) pp. 64-70, (2017),

[52] P.E.D. Love, J. Matthews, The 'how' of benefits management for digital technology: From engineering to asset management, Automation in Construction 107 pp. 102930, (2019),

https://doi.org/10.1016/j.autcon.2019.102930

[53] Y. Jiao, Y. Wang, S. Zhang, Y. Li, B. Yang, L. Yuan, A cloud approach to unified lifecycle data management in architecture, engineering, construction and facilities management: Integrating BIMs and SNS, Advanced Engineering Informatics 27 (2) pp. 173-188, (2013), https://doi.org/10.1016/i.aei.2012.11.006 
[54] Z. Ding, S. Liu, L. Liao, L. Zhang, A digital construction framework integrating building information modeling and reverse engineering technologies for renovation projects, Automation in Construction 102 pp. 45-58, (2019), https://doi.org/10.1016/j.autcon.2019.02.012

[55] G.K. Kostopoulos, Digital engineering, Wiley, New York, 1975.0471504602

[56] G.Y. Kim, J.Y. Lee, H.S. Kang, S.D. Noh, Digital Factory Wizard: an integrated system for concurrent digital engineering in product lifecycle management, International Journal of Computer Integrated Manufacturing 23 (11) pp. 1028-1045, (2010), 10.1080/0951192X.2010.511653

[57] C. McMahon, M. Giess, S. Culley, Information management for through life product support: the curation of digital engineering data, International Journal of Product Lifecycle Management 1 (1) pp. 26-42, (2005),

[58] M.A. Bone, M.R. Blackburn, D.H. Rhodes, D.N. Cohen, J.A. Guerrero, Transforming systems engineering through digital engineering, The Journal of Defense Modeling and Simulation 16 (4) pp. 339-355, (2019),

[59] Engineers Australia. 2020. What is engineering? Information about a wide range of engineering disciplines. [Online]. The Institution of Engineers Australia. Available: https://www.engineersaustralia.org.au/ForStudents-And-Educators/Engineering-Careers/What-Is-Engineering [Accessed 19 June 2020].

[60] The Defense Department. 2018. Digital Engineering Strategy [Online]. The US Defense Department. Available: https://www.defense.gov/Newsroom/Releases/Release/Article/1567723/the-department-ofdefense-announces-its-digital-engineering-strategy/ [Accessed 19 June 2020].

[61] J. Huang, A. Gheorghe, H. Handley, P. Pazos, A. Pinto, S. Kovacic, A. Collins, C. Keating, A. Sousa-Poza, G. Rabadi, Towards Digital Engineering--The Advent of Digital Systems Engineering, arXiv preprint arXiv:2002.11672 pp., (2020),

[62] Y. Rezgui, C.J. Hopfe, C. Vorakulpipat, Generations of knowledge management in the architecture, engineering and construction industry: An evolutionary perspective, Advanced Engineering Informatics 24 (2) pp. 219-228, (2010), https://doi.org/10.1016/j.aei.2009.12.001

[63] A. Shemery, K. Hampson, Developing uptake of digital engineering through industry-led research into practice approach, WEC2019: World Engineers Convention 2019, Engineers Australia, 2019, p. 259

[64] Transport and Infrastructure Council. 2016. National Digital Engineering Policy Principles [Online]. The Department of Infrastructure, Transport, Cities and Regional Development. Available:

https://www.infrastructure.gov.au/infrastructure/ngpd/files/Principles-for-DE Template 2.pdf [Accessed 13 November 2019].

[65] Transport for NSW. 2018. Digital Engineering [Online]. Available: https://www.transport.nsw.gov.au/digitalengineering [Accessed 11 November 2019].

[66] TfNSW. 2018. TfNSW Application of Uniclass 2015 [Online]. Transport for NSW. [Accessed 14 November 2019].

[67] State of Queensland. 2018. Digital Enablement for Queensland Infrastructure [Online]. Department of State Development, Manufacturing, Infrastructure and Planning. Available:

https://www.statedevelopment.qld.gov.au/resources/guideline/infrastructure/bim-principles.pdf [Accessed 14 November 2019].

[68] M. Alvesson, J. Sandberg, Ways of constructing research questions: gap-spotting or problematization?, Organization 18 (1) pp. 23-44, (2011), 10.1177/1350508410372151

[69] I. Hardcastle, S. Hubert. 2014. Digital Engineering (BIM) - Enhancing Construction Practises to Realise Greater Efficiencies in Delivery [Online]. Engineers Australia. Available:

https://www.engineersaustralia.org.au/Event/digital-engineering-bim-enhancing-construction-practisesrealise-greater-efficiencies [Accessed 20 November 2019].

[70] TfNSW. 2015. Inquiry into the role of Smart ICT in the design and planning of Infrastructure - Submission 33 [Online]. Transport for NSW. Available:

https://www.aph.gov.au/Parliamentary Business/Committees/House/ITC/Smart ICT [Accessed 20 November 2019].

[71] J. Foster. 2019. Digital Engineering Series: Part 3 - Jenny Tseng - Willow [Online]. Linkedln Corporation. Available: https://www.linkedin.com/pulse/digital-engineering-series-part-3-jenny-tseng-willow-jack-foster/ [Accessed 20 November 2019].

[72] P. Duc. 2018. From the BIM bang to digital engineering [Online]. Egis. Available: https://www.egisgroup.com/perspectives/digital-transition/bim-bang-digital-engineering [Accessed 20 November 2019]. 
[73] J. Foster. 2019. Digital Engineering Series: Part 2 - Suibhne Cullen, Mott Macdonald [Online]. Linkedln Corporation. Available: https://www.linkedin.com/pulse/digital-engineering-series-part-2-suibhne-cullenmott-jack-foster/ [Accessed 20 November 2019].

[74] M. Oraee, M.R. Hosseini, E. Papadonikolaki, R. Palliyaguru, M. Arashpour, Collaboration in BIM-based construction networks: A bibliometric-qualitative literature review, International Journal of Project Management 35 (7) pp. 1288-1301, (2017), https://doi.org/10.1016/i.ijproman.2017.07.001

[75] H.W. Ashcraft, Building information modeling: a framework for collaboration, Construction Lawyer 28 (3) pp. 5-18, (2008),

[76] TfNSW. 2019. Digital Engineering Standard - Part 1, Concepts and principles [Online]. Transport for NSW. Available: https://www.transport.nsw.gov.au/news-and-events/reports-and-publications/digitalengineering-standard-part-1-concepts-and [Accessed 20 November 2019 ].

[77] G. Dalmarco, F.R. Ramalho, A.C. Barros, A.L. Soares, Providing industry 4.0 technologies: The case of a production technology cluster, The Journal of High Technology Management Research 30 (2) pp. 100355, (2019), https://doi.org/10.1016/j.hitech.2019.100355 